\title{
Grzybica skóry twarzy imitująca krążkowy toczeń rumieniowaty
}

\section{Tinea faciei mimicking discoid lupus erythematosus}

\author{
Michał Niedźwiedź, Małgorzata Skibińska, Aleksandra Lesiak \\ Klinika Dermatologii, Dermatologii Dziecięcej i Onkologicznej Uniwersytetu Medycznego w Łodzi
}

\begin{abstract}
STRESZCZENIE
Prezentowany przypadek dotyczy kobiety, u której wystąpiły zmiany zapalne w obrębie skóry twarzy początkowo rozpoznawane jako grzybica. Wobec braku poprawy po leczeniu miejscowym oraz ujemnym badaniu mykologicznym pobrano wycinek skóry do badania histopatologicznego, który wykazał krążkową postać tocznia rumieniowatego (DLE). Miejscowo zastosowane glikokortykosteroidy oraz ogólnie chlorochina nie przyniosły poprawy. Włączone leczenie doustne $40 \mathrm{mg}$ prednizonu dziennie przyniosło pogorszenie zmian. Empirycznie rozpoznano tinea incognito i zastosowano doustnie itrakonazol. W ciągu 2 tygodni uzyskano całkowite ustąpienie zmian. Pacjentka po zakończeniu leczenia przyznała, że posiadane przez nią świnki morskie były pod opieka weterynarza z powodu zmian skórnych.
\end{abstract}

Forum Derm. 2019; 5, 4: 109-111

Słowa kluczowe: grzybica, tinea incognito, toczeń rumieniowaty krążkowy

\section{ABSTRACT}

We present a case of a female with inflammatory lesions on the face which were clinically diagnosed as tinea. Topical antifungal treatment was not helpful and direct microscopy and later culture were negative. Incisional biopsy for histopathology was taken and the report revealed discoid lupus erythematosus. As topical corticosteroids and oral chloroquine did not improve the skin lesions, $40 \mathrm{mg}$ daily of oral prednisone was introduced, causing worsening of the lesions. Tinea incognito was diagnosed empirically and the patient was treated with oral itraconazole. All skin lesions resolved within 2 weeks. The patient admitted that guinea pigs she owned at the time were under the care of a veterinarian due to skin lesions.

Forum Derm. 2019; 5, 4: 109-111

Key words: tinea faciei, tinea incognito, discoid lupus erythematosus

\section{OPIS PRZYPADKU}

Kobieta, lat 35, zgłosiła się do dermatologa z powodu ogniska rumieniowo-złuszczającego, częściowo hiperkeratotycznego na skórze nosa (ryc. 1). Pacjentka nie podawała innych chorób ani nie zgłaszała żadnych dolegliwości. Zmiana skórna pojawiła się latem. Pacjentka poinformowała, że jest właścicielką dwóch świnek morskich. Klinicznie rozważano rozpoznanie grzybicy skóry twarzy oraz krążkowej postaci tocznia rumieniowatego ( $D L E$, discoid lupus erythematosus). Pobrano zeskrobiny do badania mykologicznego oraz wykonano badania laboratoryjne (morfologia krwi, przeciwciała przeciwjądrowe) oraz włączono leczenie miejscowe kremem z 1-procentowym azotanem izokonazolu. Badania laboratoryjne nie wykazały odchyleń, a przeciwciała przeciwjądrowe były nieobecne. Wobec braku poprawy po leczeniu miejscowym oraz uzyskaniu ujemnego wyniku badania mykologicznego (badanie bezpośrednie i posiew) zdecydowano się na pobranie wycinka do badania histopatologicznego. Obraz histopatologiczny opisano jako odpowiadający rozpoznaniu DLE. Po uzyskaniu wyniku badania włączono doustnie chlorochinę w dawce $250 \mathrm{mg}$ raz dziennie oraz miejscowo 0,1-procentowy krem z furoinianem mometazonu, do stoso-

\footnotetext{
Adres do korespondencji:

dr n. med. Małgorzata Skibińska

Klinika Dermatologii, Dermatologii Dziecięcej i Onkologicznej Uniwersytetu Medycznego w Łodzi

ul. Kniaziewicza 1/5, 91-347 Łódź

tel.: +48 422516 192, e-mail: malgorzata.skibinska@umed.lodz.pl
}

Praca finansowana z funduszu prac statutowych Uniwersytetu Medycznego w Łodzi nr 503/5-064-01/503-01. 


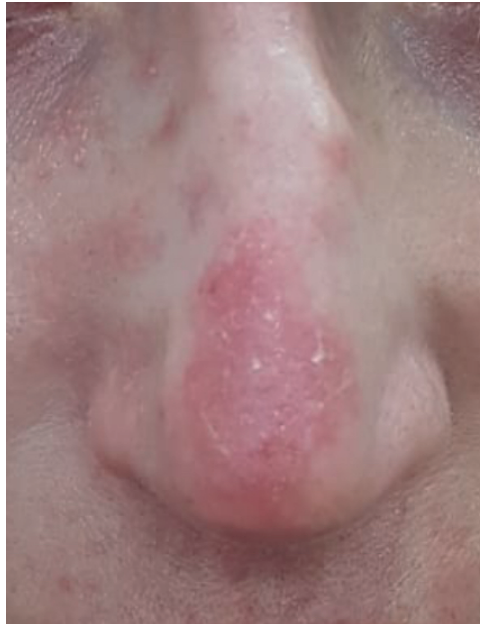

Rycina 1. Zmiany chorobowe na skórze nosa u pacjentki przed rozpoczęciem leczenia

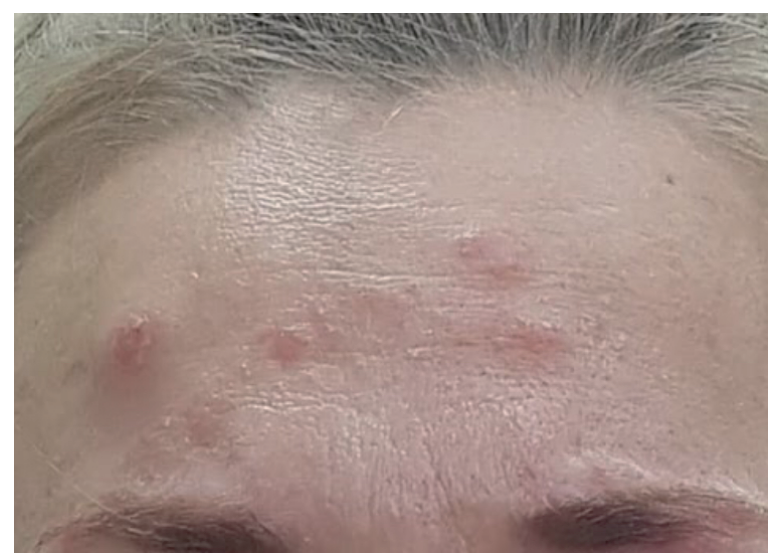

Rycina 2. Zmiany chorobowe na skórze czoła u pacjentki po leczeniu ogólnym glikokortykosteroidami

wania również raz dziennie na zmiany chorobowe. W związku z brakiem poprawy w ciągu 2 tygodni podjęto decyzję o dołączeniu prednizonu w dawce $40 \mathrm{mg}$ raz dziennie rano. Po 5 dniach zaobserwowano zdecydowane pogorszenie się zmian i empirycznie rozpoznano tinea incognito (ryc. 2, 3). Dotychczasowe leki odstawiono i zastosowano itrakonazol doustnie w dawce 200 mg raz dziennie przez 14 dni, uzyskując całkowite ustąpienie zmian chorobowych. Pacjentka w trakcie ostatniej wizyty przyznała, że świnki morskie, których jest właścicielką, były leczone przez weterynarza z powodu zmian skórnych na łapkach.

\section{DYSKUSJA}

Grzybica skóry twarzy wywoływana jest przez zakażenie dermatofitami i stanowi 3-4\% grzybic skóry [1]. Najczęściej występuje w dzieciństwie, zwykle z powodu kontaktu ze zwierzętami. Drugi szczyt jej występowania dotyczy osób

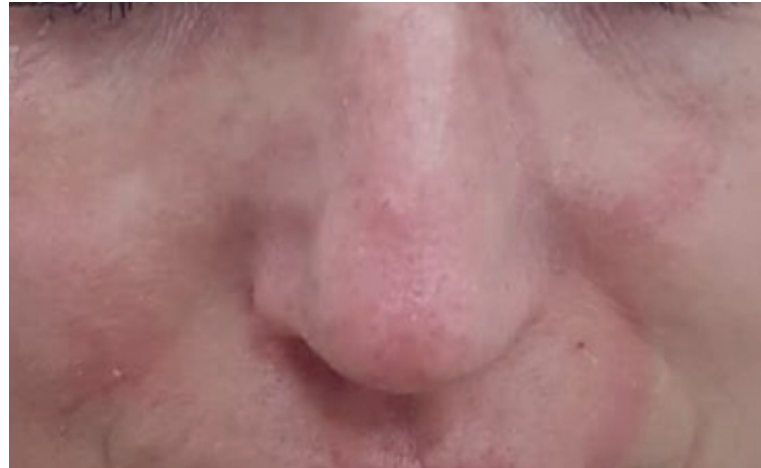

Rycina 3. Zmiany chorobowe na skórze twarzy u pacjentki po leczeniu ogólnym glikokortykosteroidami

między 20.-40. rokiem życia, co prawdopodobnie związane jest z większą aktywnością fizyczną tej grupy osób. Zwierzęta domowe i gospodarskie są częstym źródłem zakażenia, przy czym zakażenia te mogą być u zwierząt bezobjawowe [1]. Opisywana przez autorów niniejszej pracy pacjentka podawała posiadanie świnek morskich, a zmiany skórne wystąpiły na skórze nosa latem. Zmiany kliniczne sugerowały grzybicę skóry twarzy z rozpoznaniem różnicowym obejmującym DLE. W badaniu mykologicznym pobranych zeskrobin nie wykazano jednak zakażenia grzybiczego. Zgodne jest to z opinią Lina i wsp. [1] oraz Turry i wsp. [2], którzy potwierdzają, że bezpośrednie badanie mykologiczne może nie wykazać zakażenia grzybiczego, a nawet 30\% hodowli grzybów może być ujemne, zwłaszcza przy infekcjach przewlekłych.

U prawie 70\% pacjentów z grzybicą twarzy są diagnozowane inne jednostki chorobowe [1]. Rozpoznanie różnicowe grzybicy twarzy obejmuje: łojotokowe zapalenie skóry, atopowe zapalenie skóry, trądzik różowaty, zakażenia bakteryjne, kontaktowe zapalenie skóry, ziarniniaka obrączkowatego, skórne postaci tocznia rumieniowatego, sarkoidozę oraz demodekozę [1-4]. Związane jest to przede wszystkim z nietypowymi cechami klinicznymi grzybicy twarzy, których przyczyną jest najprawdopodobniej bardziej skomplikowana anatomia w tej okolicy. W obrazie klinicznym mogą pojawiać się złuszczające się plamy z lekko uniesionym brzegiem, w których obrębie mogą rozwijać się krosty, pęcherzyki i strupy [1]. Zmiany chorobowe mogą być pojedyncze lub mnogie, a zakażenie dermatofitami odzwierzęcymi może dawać więcej objawów zapalnych. Z tych powodów rozpoznanie i leczenie tego schorzenia zwykle ulega opóźnieniu [1, 2]. W związku z ujemnym badaniem mikologicznym i brakiem znaczącej poprawy po miejscowym leczeniu przeciwgrzybiczym u opisywanej pacjentki zdecydowano się na pobranie wycinka do badania histopatologicznego, którego obraz odpowiadał rozpoznaniu DLE. Rozpoznanie to było przyczyną włączenia leczenia miejscowymi glikokortykosteroidami i chlorochiną. W piśmiennic- 
twie opisywane jest często możliwe podobieństwo kliniczne grzybicy skóry i DLE $[1,5,6]$. Bardzo rzadkie są natomiast opisy badań histopatologicznych grzybicy skóry twarzy imitujących DLE [6]. U przedstawionej pacjentki włączone leczenie nie przyniosło poprawy, dlatego zdecydowano się na próbę zastosowania doustnie prednizonu w dawce $40 \mathrm{mg}$ dziennie. Już po 5 dniach terapii wystąpiło nasilenie zmian skórnych ze zmianą obrazu klinicznego, które zasugerowało rozpoznanie tinea incognito.

Tinea incognito jest zakażeniem grzybiczym o nietypowych cechach klinicznych, którego przyczyną występowania jest zwykle długotrwałe stosowanie miejscowych glikokortykosteroidów [2, 4, 5]. Jako pierwsi określenia tinea incognito użyli Ive i Marks [7] w 1968 roku opisując nierozpoznane grzybice skóry leczone miejscowymi steroidami, których zmieniony kliniczny obraz choroby może prowadzić do mylnego rozpoznania innych jednostek chorobowych, takich jak łojotokowe zapalenie skóry, liszaj płaski i trądzik różowaty. Romano i wsp. [8] w latach 1987-2002 zebrali retrospektywnie 200 przypadków pacjentów z tą jednostką chorobową. Klinicznie najczęściej zmiany przypominały ogniska wypryskowe oraz nadkażenie bakteryjne. U 7,5\% chorych rozpoznaniem klinicznym był DLE. Rzadziej opisywano zmiany o charakterze trądziku różowatego, łuszczycy, łojotokowego zapalenia skóry, liszaja płaskiego lub nawet twardziny [8, 9]. U wszystkich opisanych pacjentów bezpośrednie badanie mykologiczne było - w przeciwieństwie do prezentowanej pacjentki - dodatnie, podobnie jak posiew [8]. Leczenie ogólne itrakonazolem spowodowało szybkie ustąpienie zmian chorobowych.

Pacjentka przyznała, że często przytula świnki morskie, a w trakcie wystąpienia pierwszych zmian skórnych były one pod opieką weterynarza z powodu zmian chorobowych na łapkach. Zakażenia grzybicze lub nosicielstwo dermatofitów opisywane jest bardzo często w populacji świnek morskich. Kupsch i wsp. [10] stwierdzili obecność zoofilnego dermatofita Trichophyton benhamiae u ponad 90\% świnek morskich sprzedawanych w sklepach zoologicznych w Berlinie. Jedynie u 9\% z nich występowały objawy kliniczne grzybicy. We Francji opisano nową odmianę zoofilnego dermatofita
Trichophyton mentagrophytes var. porcellae, która była odpowiedzialna za wzrost częstości występowania grzybic skóry w populacji ludzkiej. Obecność tego grzyba stwierdzono u 2/3 świnek morskich w 3 sklepach zoologicznych w rejonie miasta Nancy [11]. Niestety, ani u pacjentki, ani u jej świnek morskich nie udało się określić gatunku grzyba odpowiedzialnego za wywołanie zmian skórnych. Identyfikacja przyczyny zakażenia i leczenie zakażonych zwierząt są istotne w celu zapobiegania infekcjom nawrotowym $[10,11]$.

\section{WNIOSKI}

Obraz kliniczny grzybicy skóry twarzy wymaga różnicowania z innymi jednostkami chorobowymi. Należy pamiętać, że badania mykologiczne, a nawet badanie histopatologiczne nie zawsze są w stanie rozstrzygnąć o właściwym rozpoznaniu choroby. Często dopiero brak efektów terapii lub pogorszenie stanu skóry mogą zasugerować zastosowanie innego leczenia.

\section{Konflikt interesów}

Autorzy nie zgłaszają konfliktu interesów.

\section{PIŚMIENNICTWO}

1. Lin RL, Szepietowski JC, Schwartz RA. Tinea faciei, an often deceptive facial eruption. Int J Dermatol. 2004; 43:437-40

2. Turra N, Navarrete J, Magliano J, Bazzano C. Follicular tinea faciei incognito: the perfect simulator. An Bras Dermatol. 2019; 94:372-74

3. Amina A, Sana M. Tinea faciei incognito. Indian Pediatr. 2019; $56: 433$

4. Paloni G, Valerio E, Berti I, Cutrone M. Tinea incognito. J Pediatr. 2015; 167:1450-e2

5. Kye H, Kim DH, Seo SH, Ahn HH, Kye YC, Choi JE. Polycyclic annular lesion masquerading as lupus erythematosus and emerging as tinea faciei incognito. Ann Dermatol. 2015; 27:322-25

6. Meymandi S, Wiseman MC, Crawford RI. Tinea faciei mimicking cutaneous lupus erythematosus: a histopathologic case report. J Am Acad Dermatol. 2003; 48:S7-8

7. Ive FA, Marks R. Tinea incognito. Br Med J 1968; 3:149-52

8. Romano C, Maritati E, Gianni C. Tinea incognito in Italy: a 15-year survey. Mycoses. 2006; 49:383-87

9. Atzori L, Pau M, Aste N, Aste N. Dermatophyte infections mimicking other skin diseases: a 154-person case survey of tinea atypica in the district of Cagliari (Italy). Int J Dermatol. 2012; 51:410-15

10. Kupsch C, Berlin M, Gräser Y. Dermophytes and guinea pigs: an underestimated danger? Hautarzt. 2017; 68:827-30

11. Bloch M, Cavignaux R, Debourgogne A, Dorin J, Machouart M, Contet-Audonneau N. From guinea pig to man: tinea outbreak due to Trichophyton mentagrophytes var. porcellae in pet shops in Nancy (France). J Mycol Med. 2016; 26:227-32 